\title{
Double-clad thulium/ytterbium co-doped octagonal-shaped fibre for fibre laser applications
}

\author{
${ }^{1}$ Babar I. M., ${ }^{1}$ Sabran M. B. S., ${ }^{2}$ Jusoh Z., ${ }^{1}$ Ahmad H., ${ }^{1,2}$ Harun S. W., \\ ${ }^{3}$ Halder A., ${ }^{3}$ Paul M. C., ${ }^{3}$ Das S. and ${ }^{3}$ Bhadra S. K. \\ ${ }^{1}$ Photonics Research Centre, University of Malaya, 50603 Kuala Lumpur, Malaysia, \\ swharun@um.edu.my \\ ${ }^{2}$ Department of Electrical Engineering, Faculty of Engineering, University of \\ Malaya, 50603 Kuala Lumpur, Malaysia \\ ${ }^{3}$ Fiber Optics and Photonics Division, Central Glass \& Ceramic Research Institute, \\ CSIR, Kolkata, India, paulmukul@hotmail.com
}

Received: 28.08 .2014

\begin{abstract}
We investigate the lasing performance of a new double-clad thulium/ytterbium co-doped octagonal-shaped fibre, basing on a cladding pump technique. The fibre is fabricated with the aid of a modified chemical vapour deposition combined with a solution doping technique. It is characterized by the $\mathrm{Tm}^{3+}-$ and $\mathrm{Yb}^{3+}$-cladding absorptions equal to 0.325 and $3.3 \mathrm{~dB} / \mathrm{m}$ respectively at 790 and $976 \mathrm{~nm}$. A triple-wavelength fibre laser operating at 1914.5, 1934.7 and $1953.6 \mathrm{~nm}$ is built that uses a $5 \mathrm{~m}$ long fibre in a ring configuration as a gain medium. With the fibre as long as $15 \mathrm{~m}$, the ring laser produces the highest output power of $21.9 \mathrm{~mW}$ at the pump power of $3600 \mathrm{~mW}$, with the lowest threshold pump power being equal to $1000 \mathrm{~mW}$. When operating at $1961.4 \mathrm{~nm}$, the maximal efficiency of 0.88 per cent is achieved for the gain medium length fixed at $10 \mathrm{~m}$. We also demonstrate a Q-switched thulium/ytterbium-doped fibre laser that operates at $1977.5 \mathrm{~nm}$ and utilizes multi-walled carbon nanotubes as a gain medium. By varying the multimode $905 \mathrm{~nm}$ pump power from 1591.3 to $2261.5 \mathrm{~mW}$, one can increase the pulse repetition rate from 18.8 to $50.6 \mathrm{kHz}$, while the pulse width then decreases from 8.6 to $1.0 \mu \mathrm{s}$. The maximum pulse energy $5.71 \mathrm{~nJ}$ is obtained at the pump power $2100 \mathrm{~mW}$.
\end{abstract}

Keywords: $2 \mu \mathrm{m}$ Q-switched fibre lasers, thulium/ytterbium co-doped fibres, multiwalled carbon nanotubes, saturable absorbers

PACS: $42.60 . \mathrm{Da}, 42.55 . \mathrm{Wd}$

UDC: $621.375 .826+615.849 .19+681.7 .068$

\section{Introduction}

Fibre lasers doped with thulium $\left(\mathrm{Tm}^{3+}\right)$ are of great interest for generating coherent emission in the 'eye-safe' wavelength range. Their emission bands extend over a wide range from $1.6 \mu \mathrm{m}$ to above $2 \mu \mathrm{m}$, and they can be efficiently pumped at approximately 790, 1200 or $1600 \mathrm{~nm}[1,2]$. These features make thulium-doped fibre lasers attractive for a variety of applications in spectroscopy, materials processing, and defence [3-5]. Since the radiation near $2 \mu \mathrm{m}$ reveals strong absorption in water and biological tissues, the lasers mentioned above have also a number of potential applications in various fields of medicine. In particular, incisions in porcine tissue and chicken breast have recently been checked with a continuous-wave $1.98 \mu \mathrm{m}$ Tm-doped fibre laser [6]. Moreover, the penetration depth of the $2 \mu \mathrm{m}$ laser radiation matches the subcutaneous depths of pain nerve receptors in the skin such that the corresponding lasers make an almost ideal source for experimental pain 
researches, since the damage on skin surfaces can be minimized [7]. Recently, interactions of tissue with the radiation of Q-switched thulium-doped fibre lasers have also been reported [8].

Sufficient quantum efficiency near $2 \mu \mathrm{m}$ can be achieved for the ${ }^{3} \mathrm{~F}_{4}$ to ${ }^{3} \mathrm{H}_{6}$ transition in thulium ions because of a so-called cross-relaxation energy transfer among those ions. During the cross-relaxation energy transfer process, two ground-level thulium ions can be excited to the upper lasing level of the ${ }^{3} \mathrm{~F}_{4}-{ }^{3} \mathrm{H}_{6}$ transition after absorbing a single pump photon near $790 \mathrm{~nm}$. This means that one excited $\mathrm{Tm}^{3+}$ ion at the ${ }^{3} \mathrm{H}_{4}$ level generates two $\mathrm{Tm}^{3+}$ ions at the upper laser level ${ }^{3} \mathrm{~F}_{4}$ [9]. However, the availability of commercial high-power diodes in this wavelength region, with the power levels higher than $100 \mathrm{~W}$, is relatively poor and these sources are very costly. Pumping $\mathrm{Tm}^{3+}$-doped fibres at 1200 or $1600 \mathrm{~nm}$ is complicated by a need in intermediate laser sources, because the high-power laser diodes operating at this wavelength are not commercially available. However, there exists an alternative approach. It foresees co-doping these fibres with $\mathrm{Yb}^{3+}$ and pumping them at $905-980 \mathrm{~nm}$. The matter is that the $\mathrm{Tm}^{3+}$ ion has a level ${ }^{3} \mathrm{H}_{5}$, which is (quasi-) resonant with the excited $\mathrm{Yb}^{3+}$ level $\left({ }^{2} \mathrm{~F}_{5 / 2}\right)$, thus allowing for sensitization of $\mathrm{Tm}^{3+}$-doped fibres with $\mathrm{Yb}^{3+}$, similar to the case of $\mathrm{Yb}^{3+}$-sensitized $\mathrm{Er}^{3+}$-doped fibres studied earlier [10, 11$]$.

On the other hand, there is a growing interest in compact Q-switched laser sources operating in the mid-infrared spectral region (around $2 \mu \mathrm{m}$ ). It is driven mainly by various applications in the spectroscopy, optical communications, materials processing, manufacturing, sensing, medicine, and nonlinear optics $[12,13]$. Unlike active Q-switching, its passive counterpart represents more convenient and cost-effective way to achieve high-energy pulses because it requires no additional switching electronics. Passive Q-switching of $2 \mu \mathrm{m}$ fibre lasers has so far been realized with a number of techniques, including multiple quantum wells [14] and Cr:ZnS or Cr:ZnSe crystals [15, 16]. However, all of these implementations require additional bulk components (mirrors, lens pairs, etc.), thus compromising such key benefits of the fibre lasers as compactness and alignmentfree operation. Passive Q-switching has long been dominated by semiconductor saturable absorber mirrors (SESAMs), carbon nanotubes, and graphene $[13,17,18]$. They reveal key advantages such as ultrafast recovery time, wide operating bandwidth, and easy integration with fibre optic systems. Recently, a new member of carbon nanotube family called 'multi-walled carbon nanotubes' (MWCNTs) [19, 20] has captured some attention concerned with Q-switching applications, since it promises to become an alternative to single-walled carbon nanotubes (SWCNTs). The MWCNTs have the characteristics similar to those of SWCNTs but differ by notably lower (50-80\%) production costs. When compared to the SWCNTs, the MWCNTs manifest also higher mechanical strength, photon absorption per nanotube and thermal stability, owing to their higher mass density [20].

In this work we investigate lasing performance of a new double-clad, octagonal-shaped thulium/ytterbium-doped fibre (TYDF). A TYDF laser (TYDFL) suggested and built by us operates in the wavelength region near $2000 \mathrm{~nm}$. It is based on the energy transfer $\mathrm{Yb}^{3+} \rightarrow \mathrm{Tm}^{3+}$ and employs multimode pumping at about $905 \mathrm{~nm}$. We also demonstrate operation of a Q-switched, all-fibre ring-type TYDFL which uses a newly developed MWCNTs-based saturable absorber (SA) as a Q-switcher. This SA is constructed by sandwiching a MWCNT-polyvinyl alcohol (MWCNT-PVA) film between two fibre connectors.

\section{Fabrication of TYDF}

A double-clad octagonal-shaped TYDF was fabricated with a modified chemical vapour deposition technique combined with a solution doping method. A pure silica glass tube of 
outer/inner diameters 20/17 mm was used for depositing two porous unsintered $\mathrm{SiO}_{2}$ soot layers to make a preform, while maintaining a suitable deposition temperature at $\sim 1550^{\circ} \mathrm{C}$. An alcoholic solution containing such doping elements as thulium, ytterbium, yttrium and aluminium was used to soak the porous layer for about $30 \mathrm{~min}$ and achieve efficient doping. Then dehydration and oxidation were performed at about $900-1000^{\circ} \mathrm{C}$. Unsintered layers were sintered by slowly increasing the temperature from 1500 to $2000^{\circ} \mathrm{C}$ and using a conventional modified chemical vapour deposition technique. Upon completion of sintering and oxidation, a tube was slowly collapsed to be converted into optical preform. The dopant concentration inside the preform was analyzed with an electron probe micro-analyser. It was found that the optical preform thus fabricated consisted of $\mathrm{Al}_{2} \mathrm{O}_{3}, \mathrm{Y}_{2} \mathrm{O}_{3}, \mathrm{Tm}_{2} \mathrm{O}_{3}$ and $\mathrm{Yb}_{2} \mathrm{O}_{3}$ dopants, with the corresponding average weight percentages of 5.5, 3.30, 0.70 and 4.0, respectively. The presence of $\mathrm{Al}_{2} \mathrm{O}_{3}$ and $\mathrm{Y}_{2} \mathrm{O}_{3}$ served to decrease the phonon energy of alumino-silica glass, which prevented clustering of $\mathrm{Yb}$ and $\mathrm{Tm}$ ions into the core glass matrix and, therefore, increased the probability of radiative emission.

The circular preform fabricated in the above manner was given an octagonal shape after grinding followed by polishing. This geometrically modified preform was then drawn at $2050^{\circ} \mathrm{C}$ to fabricate an octagonal-shaped double-clad fibre with the outer cladding diameter of about $125 \mu \mathrm{m}$. The double-clad fibre was finally coated with a low-refractive index polymer to increase robustness of the fibre. As opposed to a conventional core pumping technique, the pump light in our case propagated in the first cladding of the fibre and then was absorbed by $\mathrm{Yb}$ dopants in the regions where the clad was overlapped with the core. The octagonal geometry was chosen for improving the pump absorption efficiency. The doping levels of $\mathrm{Tm}^{3+}$ and $\mathrm{Yb}^{3+}$ ions in the TYDF (about 4.85 and $27.3 \mathrm{ions} / \mathrm{cc}$, respectively) were measured with the electron probe micro-analyser. The $\mathrm{Tm}^{3+}$ - and $\mathrm{Yb}^{3+}$-cladding absorptions of the fibre were found to be 0.325 and $3.3 \mathrm{~dB} / \mathrm{m}$ respectively at 790 and $976 \mathrm{~nm}$.

\section{Lasing characteristics of TYDF}

Lasing characteristics of the TYDF have been studied for both ring and linear configurations. Fig. 1 shows the experimental setup of our ring TYDFL. It consists of a piece of TYDF that serves as a gain medium, a multimode combiner (MMC), a $10 \mathrm{~dB}$ output coupler, and a $905 \mathrm{~nm}$ laser diode as an optical pump source. Inset in Fig. 1 displays a microscopic view of TYDF cross-

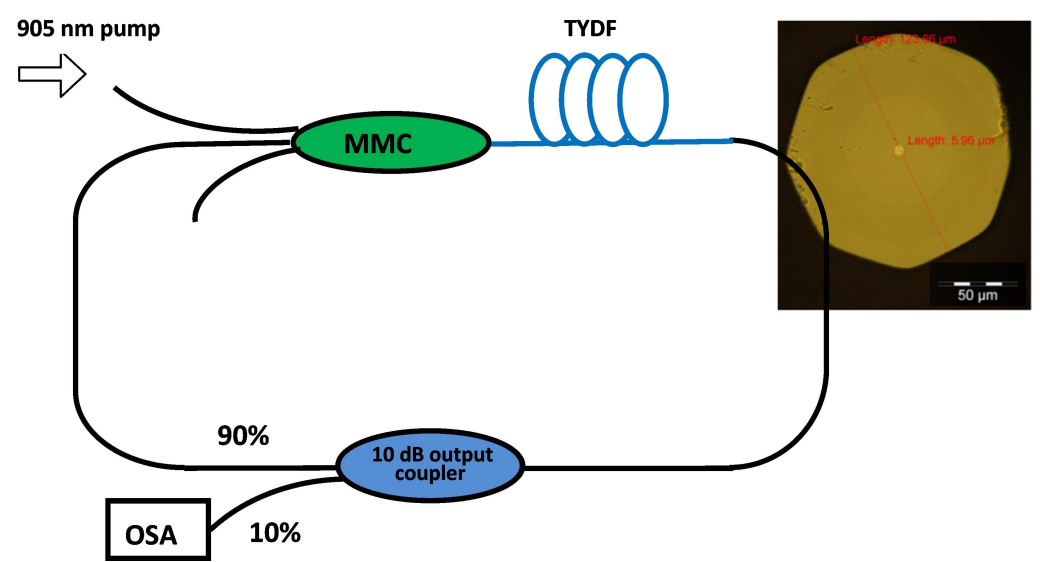

Fig. 1. Experimental setup of our TYDFL in the ring configuration. OSA is optical spectrum analyzer. Inset shows microscopic cross-sectional view of our double-clad octagonal-shaped TYDF. 
section, which has an octagonal-shaped inner cladding. The core diameter and the numerical aperture of our TYDF are equal to $5.96 \mu \mathrm{m}$ and 0.23 , respectively. We have investigated performance of the laser for three different fibre lengths $(5,10$ and $15 \mathrm{~m})$. It has turned out that an amplified spontaneous emission centred nearby $1950 \mathrm{~nm}$ is generated after the fibre is pumped by the multimode $950 \mathrm{~nm}$ laser diode. The power of this emission increases with increasing pump power. The amplified spontaneous emission oscillates in the ring cavity, resulting in a lasing that occurs at $\sim 1.95 \mu \mathrm{m}$. The laser output is then tapped from the $10 \mathrm{~dB}$ coupler for further characterization. The coupler allows for $90 \%$ of the light to oscillate in the laser cavity while tapping out the remaining $10 \%$ of the light. Notice that our laser device contains no adjustable parts and can only be controlled externally by the amount of pump power applied to TYDFs of three different lengths.

Fig. 2 shows the dependences of output power on the pump power for the three different fibre lengths. The output power increases linearly with increasing pump power, with the slopes 0.29 , 0.88 and $0.77 \%$ characteristic for the TYDF lengths 5,10 and $15 \mathrm{~m}$, respectively. As said above, the TYDFL operates basing on the energy transfer from ytterbium to thulium ions. As the $905 \mathrm{~nm}$ pump photons are absorbed by the ytterbium ions, they excite the ions from the ground state ${ }^{2} \mathrm{~F}_{7 / 2}$ onto the ${ }^{2} \mathrm{~F}_{5 / 2}$ level. As the ion relaxes to its ground state, the energy transfer proceeds to a neighbouring thulium ion. When the thulium ions in their ground state $\left({ }^{3} \mathrm{H}_{6}\right)$ absorb the donated photons they get elevated to the ${ }^{3} \mathrm{H}_{5}$ level before irradiatively relaxing to ${ }^{3} \mathrm{~F}_{4}$. The thulium ions populating this level drop to the ground state again, generating the amplified spontaneous emission in the vicinity of $1.95 \mu \mathrm{m}$, which oscillates in the ring cavity and brings about a laser light. We have obtained the threshold pump powers for our laser as low as 1000, 2044 and $1000 \mathrm{~mW}$ for the 5, 10 and $15 \mathrm{~m}$ long TYDFs, respectively. The corresponding maximal output powers are $8,13.7$ and $21.9 \mathrm{~mW}$, as measured at the maximal pump power of $3.6 \mathrm{~W}$. The efficiency of our laser is the highest $(0.88 \%)$ for the $10 \mathrm{~m}$ long TYDF, while the $15 \mathrm{~m}$ long fibre provides the highest output power $(21.9 \mathrm{~mW})$, which is attributed to the lowest threshold pump power. These facts indicate that the optimal length of the fibre in the ring TYDFL is somewhere in the region of 10-15 m.



Fig. 2. Output power of our ring TYDFL versus the pump power as measured at three different TYDF lengths.

The output spectra of the ring TYDFL have been studied for the same three different TYDF lengths. The results are shown in Fig. 3 where the multimode $905 \mathrm{~nm}$ pump power is fixed at $3.6 \mathrm{~W}$. It is seen that the output spectrum shifts to longer wavelengths with increasing TYDF length. This is attributed to increased absorption of the $905 \mathrm{~nm}$ photons, which takes place with increasing fibre length and so results in increased number of the emitted photons. These photons 
are re-absorbed by thulium ions along the fibre length, imposing the amplified spontaneous emission at a longer wavelength, which oscillates in the cavity and leads to the lasing effect. With the $5 \mathrm{~m}$ long TYDF, the laser produces three lines $(1914.5,1934.7$ and $1953.6 \mathrm{~nm})$, with the peak powers being equal respectively to $6.3,1.6$ and $1.7 \mathrm{dBm}$. On the other hand, the laser operates at a single wavelength (1961.4 nm), with the peak power of $4.8 \mathrm{dBm}$, as the TYDF length increases to $10 \mathrm{~m}$. Further increase in the TYDF length up to $15 \mathrm{~m}$ yields in a dual-wavelength output (1562.7 and $1990.3 \mathrm{~nm}$ ). These results indicate that the optimal TYDF length for our ring cavity is about $10 \mathrm{~m}$, when the side modes are significantly suppressed, allowing a single-wavelength operation. We have also observed that the operating wavelength shifts toward longer wavelengths with increasing pump power.

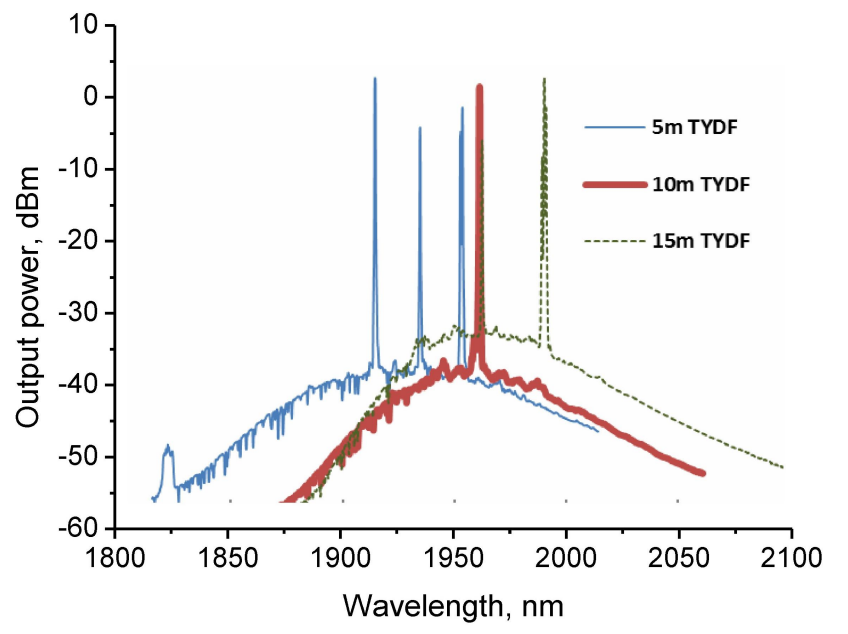

Fig. 3. Output spectra of our ring TYDFL as measured for different TYDF lengths.

We have also studied the lasing characteristics of our TYDF for the case of linear cavity configuration (see Fig. 4). In the experiment, a linear cavity is formed in between an optical circulator, which is used to re-route the back-propagating light back into the cavity, and a splicing point located between the other end of TYDF and a standard single-mode fibre. Ports 3 and 1 of the circulator are spliced together so that the circulator can reflect back the incoming light from a port 2. The mode mismatch between the TYDF and the single-mode fibre reflects a small portion of light ( $\sim 3 \%)$ back into the cavity due to Fresnel reflection. By cladding pumping of the doubleclad TYDF, the amplified spontaneous emission is generated in the vicinity of $1950 \mathrm{~nm}$. It oscillates in the linear cavity and produces a laser light. The device starts to lase above some threshold pump power that depends on the fibre length. Fig. 5 shows the output power of the laser versus the pump power at three different gain-medium lengths. As seen from Fig. 5, the output laser power increases almost linearly with increasing pump power. The threshold pump powers 1300,1400 and $1500 \mathrm{~mW}$ are typical for the 10,15 and $5 \mathrm{~m}$ long fibres, respectively. The maximal

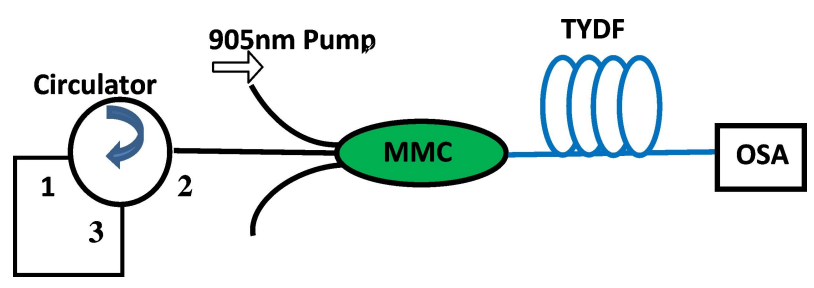

Fig. 4. Experimental setup of our TYDFL in the linear configuration. OSA is optical spectrum analyzer.

Ukr. J. Phys. Opt. 2014, Volume 15, Issue 4 
output power $(17.6 \mathrm{~mW})$ is achieved when the pump power is equal to $3.56 \mathrm{~W}$ (for the case of 15 $\mathrm{m}$ long fibre).

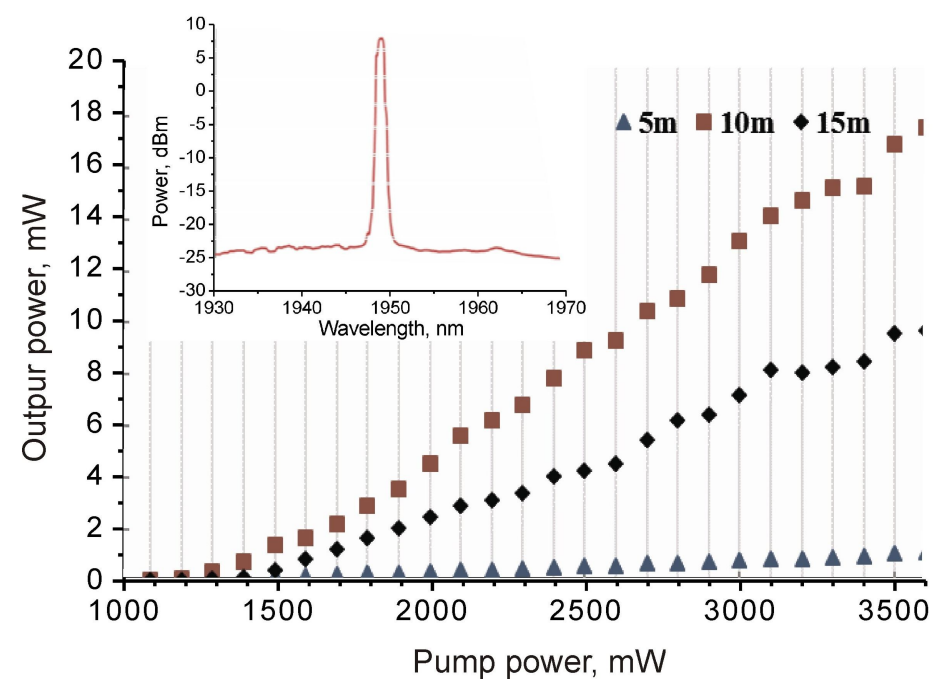

Fig. 5. Output power of our linear TYDFL versus the pump power as measured at three different TYDF lengths. Inset shows output spectrum of the TYDFL configured with $10 \mathrm{~m}$ long gain medium.

The data of Fig. 5 testifies that, among the three fibre lengths under test, the $10 \mathrm{~m}$ long TYDF provides both the maximal output power and the minimal threshold. The slope efficiencies 0.75 , 0.42 and $0.04 \%$ are peculiar for the 10,15 and $5 \mathrm{~m}$ long fibres, respectively. Therefore the optimal gain-medium length for the linear TYDFL is $10 \mathrm{~m}$. Nonetheless, the efficiency thus obtained is lower if compared to that typical of the ring TYDFL. This is because the 'mirrors' are built on simply using the Fresnel reflections, thus increasing significantly the cavity losses. Optimization of the output reflector is expected to improve the attainable efficiency and so the output power of our laser.

The inset in Fig. 5 displays the output spectrum of our linear TYDFL for the case when the TYDF length is fixed at $10 \mathrm{~m}$. As seen from Fig. 5, the laser operates at $1949.2 \mathrm{~nm}$, with the signal-to-noise ratio higher than $30 \mathrm{~dB}$. Notice also that the operating wavelength is slightly shorter than that obtained for the ring cavity. This is attributed to higher losses for the linear cavity, when compared to the ring one. Indeed, higher losses shift the operating wavelength toward shorter wavelengths which have a higher gain to compensate for those losses.

\section{Q-switched TYDFL}

Fig. 6 shows a scheme of a Q-switched TYDFL suggested in this work, which uses a simple ring cavity. In the cavity, a $10 \mathrm{~m}$ long TYDF is introduced as an active medium and a homemade SA as a Q-switcher. The SA is fabricated using dispersed MWCNTs. To match the TYDFL operating near $2 \mu \mathrm{m}$, choosing of MWCNTs with suitable mean diameter and distribution range of the diameters represents a critical point. In this work, we have utilized the SWCNTs with the purity of $99 \%$, the diameters of $10-20 \mathrm{~nm}$ and the lengths of 1-2 $\mu \mathrm{m}$. The host material is PVA, which represents a water-soluble synthetic polymer with the monomer formula $\mathrm{C}_{2} \mathrm{H}_{4} \mathrm{O}$. It has excellent film-forming, emulsifying and adhesive properties. Moreover, the PVA manifests high tensile strength, flexibility, and high oxygen and aroma barriers, although these properties slightly depend on the humidity of environment. 




Fig. 6. Experimental setup of our Q-switched TYDFL. OSA is optical spectrum analyzer. Insets show image of an MWCNTs-PVA film attached onto a fibre ferrule, as well as the corresponding Raman spectrum.

At first a functionalizer solution was prepared by dissolving $4 \mathrm{~g}$ of sodium dodecyl sulphate in $400 \mathrm{ml}$ of deionized water. $250 \mathrm{mg}$ of MWCNTs was added to the solution and a homogenous dispersion of MWCNTs was achieved after the mixed solution had been sonicated for 60 minutes (the power $50 \mathrm{~W}$ ). Then the solution was centrifuged at $1000 \mathrm{rpm}$ to remove large particles of undispersed MWCNTs and so obtain a stable dispersed suspension. A MWCNTs-PVA composite was prepared by adding a dispersed MWCNTs suspension to PVA solution according to the ratio 1:4. The PVA solution was prepared by dissolving $1 \mathrm{~g}$ of PVA (M.W. $=89 \times 103 \mathrm{~g} / \mathrm{mol}$ ) in $120 \mathrm{ml}$ of deionized water. A homogeneous MWCNTs-PVA composite was obtained with a sonification process lasting for more than $1 \mathrm{~h}$. The MWCNTs-PVA composite was placed into a glass Petri dish and left to dry at the room temperature for about one week to produce a film with the thickness of about $50 \mu \mathrm{m}$.

The SA was fabricated by cutting a small part of the prepared film $\left(2 \times 2 \mathrm{~mm}^{2}\right)$, as shown in the inset of Fig. 6. It was sandwiched between two FC/PC fibre connectors after depositing indexmatching gel onto the fibre ferrules. The insertion loss of the SA was measured to be approximately $3 \mathrm{~dB}$ at $1950 \mathrm{~nm}$. The inset of Fig. 6 displays also the Raman spectrum of the MWCNT-PVA film. The spectrum unambiguously reveals two well-defined peaks positioned at 1585 and $1433 \mathrm{~cm}^{-1}$, which correspond respectively to so-called $\mathrm{G}$ and D bands. In addition, a distinguishable feature at $2900 \mathrm{~cm}^{-1}$ and a small peak at $848 \mathrm{~cm}^{-1}$ are observed. Note that a known important feature, a radial low-energy 'breathing mode', located at the Raman shift of about $100-400 \mathrm{~cm}^{-1}$, is not seen in our spectrum, though it is usually observed for the SWCNTs films. The reason may be the fact that our MWCNTs have many layers of graphene wrapped around the core tubes, which restrict the 'breathing mode'.

The double-clad TYDF was forward-pumped by the same multimode $905 \mathrm{~nm}$ laser diode via an MMC. The laser output was obtained via a $10 \mathrm{~dB}$ output coupler located between the SA and the MMC, which channelled out about $10 \%$ of the oscillating light from the ring cavity. The cavity length was approximately equal to $15 \mathrm{~m}$. We used an optical spectrum analyzer for the spectral analysis of the Q-switched TYDFL. An oscilloscope combined with a photodetector were utilized to observe the output pulse train as a result of Q-switched laser operation. All of the components involved in our setup were polarization-independent, i.e. they supported arbitrary light polarizations. No polarization controller was inserted into the laser cavity as we had observed earlier that it did not improve the pulse stability. During our experiment, oscilloscopic 
observations have revealed no significant pulse jitter. Finally, the lasing threshold was approximately equal to $1.6 \mathrm{~W}$.

After inserting the SA into the scheme we have obtained a stable and self-starting Q-switching operation just by adjusting the pump power over the threshold of $1.6 \mathrm{~W}$ as mentioned above. Fig. 7 illustrates the output spectrum of the Q-switched TYDFL measured under conditions that the multimode $905 \mathrm{~nm}$ pump power is just equal to the threshold. As seen from Fig. 7, the laser operates at the wavelength of $1977.5 \mathrm{~nm}$, the optical signal-to-noise ratio amounts to about $30 \mathrm{~dB}$, and the $3 \mathrm{~dB}$ bandwidth is approximately $0.4 \mathrm{~nm}$. There is no chirp in the optical spectrum inside the peak-wavelength region, thus indicating that the cavity perturbations are successfully suppressed. Fig. 8a and Fig. 8b show respectively the oscilloscope traces of the pulse train and the single pulse envelop, which are typical for our Q-switched laser at the same pump power 1.6 W. The spacing between the neighbouring pulses in Fig. $8 \mathrm{a}$ is nearly equal to $53 \mu \mathrm{s}$, which implies the repetition rate of $18.8 \mathrm{kHz}$. The corresponding pulse width turns out to be about $8.6 \mu \mathrm{s}$.

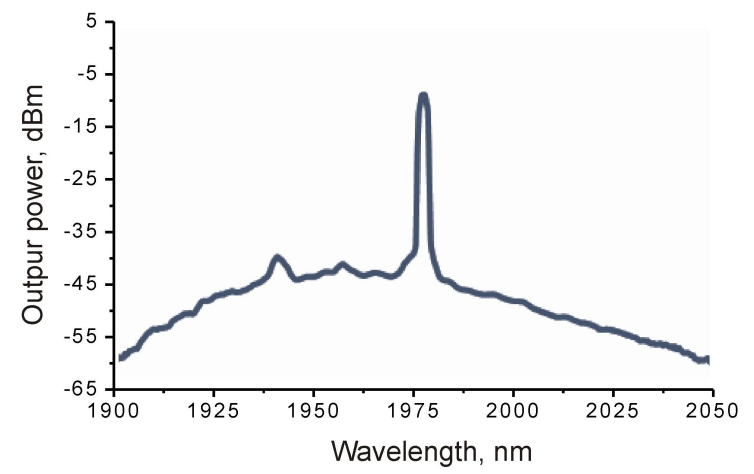

Fig. 7. Output spectrum of our Q-switched TYDFL measured at the threshold pump power of $1.6 \mathrm{~W}$.

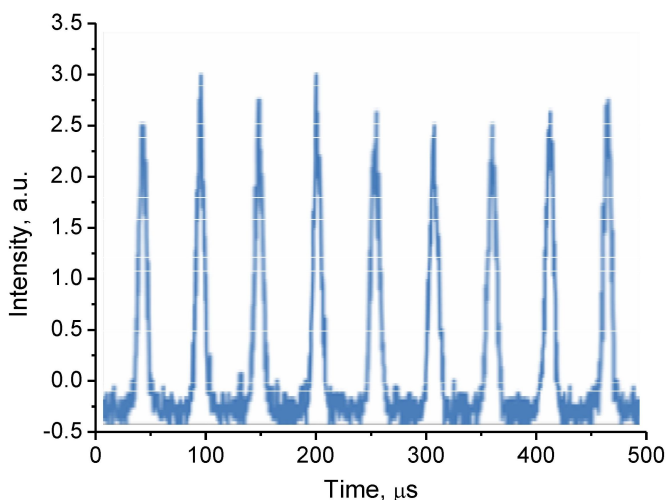

(a)

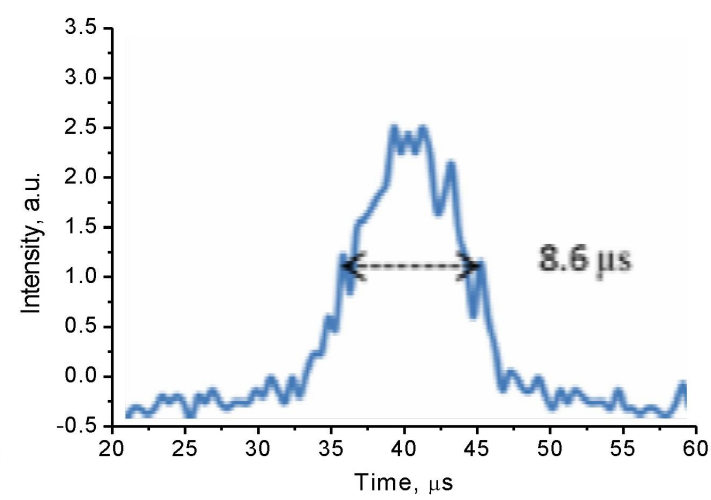

(b)

Fig. 8. A pulse train (a) and a single pulse envelop (b) measured for our Q-switched TYDFL at the threshold pump power of $1.6 \mathrm{~W}$. The repetition rate is equal to $18.8 \mathrm{kHz}$ and the pulse width is $8.6 \mu \mathrm{s}$

It has come to our attention that both the repetition rate and the pulse width of the Q-switched pulses can be sensitive to the pump power. We have observed that the Q-switched pulse generation starts at the pump threshold, of which exact value is $1591.3 \mathrm{~mW}$, and disappears as the pump power increases above $2261.5 \mathrm{~mW}$. The dependences of the repetition rate and the pulse width on the input pump power are depicted in Fig. 9. It follows from Fig. 9 that the repetition rate increases almost linearly with increasing pump power. This result agrees well with the inherent 
characteristics of Q-switched fibre lasers reported earlier (see Ref. [10]). In the pump power region under study, the pulse repetition rate increases from 18.8 to $50.6 \mathrm{kHz}$, while the pulse width decreases from 8.6 to $1.0 \mu \mathrm{s}$. Notice that the pulse duration could be further narrowed by optimizing the parameters involved. This includes shortening the cavity length and improving the modulation depth of the MWCNTs Q-switcher.

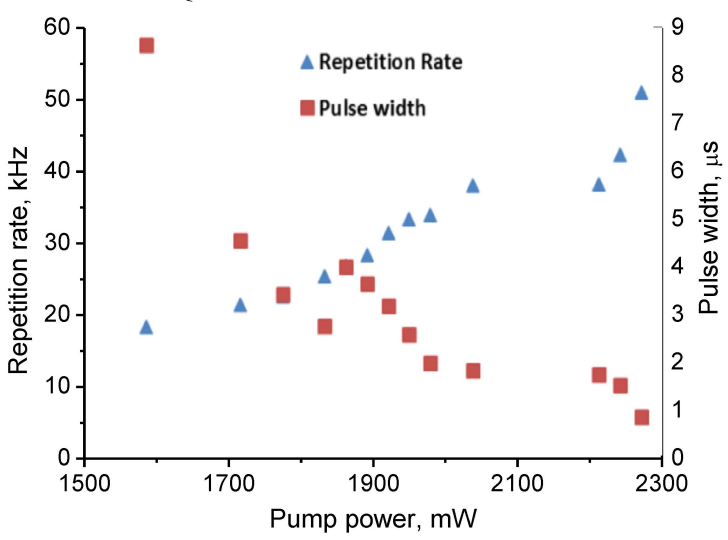

Fig. 9. Repetition rate and pulse width of our Q-switched TYDFL as functions of the pump power.

Finally, we have measured the average output power and, in this basis, calculated a singlepulse energy (see Fig. 10). Both the average output power and the pulse energy increase almost linearly when the input pump power increases from 1591.3 to $2100 \mathrm{~mW}$. However, as the pump power becomes still higher, the both quantities under test begin to saturate and then decrease. At $2100 \mathrm{~mW}$, the maximal output power $0.21 \mathrm{~mW}$ is obtained, which corresponds to the maximal pulse energy $5.71 \mathrm{~nJ}$. Higher pulse energies could be reached by further optimizing the doubleclad fibre for achieving higher gains and optimizing the cavity design for reducing the cavity losses.



Fig. 10. Output power and pulse energy of our Q-switched TYDFL as functions of the $905 \mathrm{~nm}$ pump power.

\section{Conclusion}

We have demonstrated successful operation of both multi-wavelength and Q-switched fibre lasers based on a newly developed double-clad octagonal-shaped TYDF and a multimode optical pumping at $905 \mathrm{~nm}$. The fibre manifests the $\mathrm{Tm}^{3+}$ - and $\mathrm{Yb}^{3+}$-cladding absorptions equal respectively to 0.325 and $3.3 \mathrm{~dB} / \mathrm{m}$ at the wavelengths of 790 and $976 \mathrm{~nm}$. It is fabricated with the 
modified chemical vapour deposition technique combined with the solution doping method. A triple-wavelength laser operating at 1914.5, 1934.7 and $1953.6 \mathrm{~nm}$ has been implemented, using a $5 \mathrm{~m}$ long TYDF in a ring configuration. The laser operates at $1961.4 \mathrm{~nm}$ and ensures the maximal efficiency $0.88 \%$ with a $10 \mathrm{~m}$ long TYDF.

When incorporating a homemade MWCNTs-based SA into a ring cavity, we have obtained a Q-switching pulse train occurring at $1977.5 \mathrm{~nm}$. By varying the multimode pump power at the wavelength of $905 \mathrm{~nm}$ from 1591.3 to $2261.5 \mathrm{~mW}$, we have been able to increase the relevant pulse repetition rate from 18.8 to $50.6 \mathrm{kHz}$ and decrease the pulse width from 8.6 to $1.0 \mu \mathrm{s}$. A Q-switching with higher performance can be achieved for our fibre laser through optimizing the gain medium, the SA and the laser cavity.

\section{Acknowledgement}

This work has been funded by the Ministry of Higher Education under ERGS (Grant No ER0122012A) and University of Malaya (Grant No PG068-2013B).

\section{References}

1. Clarkson W A, Barnes N. P, Turner P. W, Nilsson J and Hanna D C, 2002. High-power cladding-pumped Tm-doped silica fiber laser with wavelength tuning from 1860 to $2090 \mathrm{~nm}$. Opt. Lett. 27: 1989-1991.

2. Zen D I M, Saidin N, Damanhuri S S A, Harun S W, Ahmad H, Ismail M A, Dimyati K, Halder A, Paul M C, Das S, Pal M and Bhadra S K, 2013. Mode-locked thulium-bismuth codoped fiber laser using graphene saturable absorber in ring cavity. Appl. Opt. 52: 12261229.

3. Eichhorn M, 2010. Pulsed $2 \mu \mathrm{m}$ fiber lasers for direct and pumping applications in defense and security. Proc. SPIE 7836, Technol. for Opt. Countermeasures VII. 78360B (to be published).

4. Theisen-Kunde D, Tedsen S, Herrmann K, Danckie V, and Brinkmann R, 2007. Partial kidney



5. Baudelet M, Willis C C C, Shah L and Richardson M, 2010. Laser-induced breakdown spectroscopy of copper with a $2 \mu \mathrm{m}$ thulium fiber laser. Opt. Express. 18: 7905-7910.

6. Pierce MC, Jackson S D, Dickinson MR and King TA, 1999. Laser-tissue interaction with a high-power 2- $\mu \mathrm{m}$ fiber laser: Preliminary studies with soft tissue. Laser Surg. Med. 25: 407413.

7. Opsommer E, Weiss T, Miltner W H R and Plaghki L, 2001. Scalp topography of ultralate (Cfibres) evoked potentials following thulium YAG laser stimuli to tiny skin surface areas in humans. Clin. Neurophysiol. 112: 1868-1874.

8. El-Sherif A F and King T A, 2003. Soft and hard tissue ablation with short-pulse high peak power and continuous thulium-silica fibre lasers. Lasers Med. Sci. 18: 139-147.

9. Jackson S D, 2004. Cross relaxation and energy transfer upconversion processes relevant to the functioning of $2 \mu \mathrm{m} \mathrm{Tm} 3+$-doped silica fibre lasers. Opt. Commun. 230: 197-203.

10. Halder A, Paul MC, Damanhuri SSA, Huri NAD, Hamzah A, Harun SW, Ahmad H, Das S, Pal $\mathrm{M}$ and Bhadra SK, 2012. Upconversion luminescence in $\mathrm{Tm}^{3+} / \mathrm{Yb}^{3+}$ co-doped double-clad silica fibers under $980 \mathrm{~nm}$ cladding pumping. J. Mod. Opt. 59: 527-532.

11. Harun S W, Saidin N, Damanhuri S S A, Ahmad H, Halder A, Paul M C, Das S, Pal M and Bhadra S K, 2012. Fiber laser at 2 micron region using double-clad thulium/ytterbium codoped yttria-alumino-silicate fiber. Laser Phys. Lett. 9: 50-53.

12. Anyi C L, Ali N M, Rahman A A, Harun S W and Arof H, 2013. Multi-wavelength Q- 
switched erbium-doped fibre laser using saturable absorber based on carbon nanotube film. Ukr. J. Phys. Opt. 14: 212-218.

13. Harun S W, Ismail M A, Ahmad F, Ismail M F, Nor R M, Zulkepely N R and Ahmad H, 2012. A Q-switched erbium-doped fiber laser with a carbon nanotube based saturable absorber. Chinese Phys. Lett. 29: 114202.

14. Kivisto S, Koskinen R, Paajaste J, Jackson S D, Guina M and Okhotnikov O G, 2008. Passively Q-switched $\mathrm{Tm}^{3+}, \mathrm{Ho}^{3+}$-doped silica fiber laser using a highly nonlinear saturable absorber and dynamic gain pulse compression. Opt. Express. 16: 22058-22063.

15. Qamar F Z and King T A, 2005. Passive Q-switching of the Tm-silica fiber laser near $2 \mu \mathrm{m}$ by $\mathrm{Cr}^{2+}: \mathrm{ZnSe}$ saturable absorber crystal. Opt. Commun. 248: 501-505.

16. Tang Y, Yang Y, Xu J and Hang Y, 2008. Passive Q-switching of short-length $\mathrm{Tm}^{3+}$-doped silica fiber lasers by polycrystalline $\mathrm{Cr}^{2+}: \mathrm{ZnSe}$ microchips. Opt. Commun. 281: 5588-5591.

17. Chernysheva M A, Krylov A A, Arutyunyan N R, Pozharov A S, Obraztsova E D and Dianov E M, 2014. SESAM and SWCNT mode-locked all-fiber thulium-doped lasers based on the nonlinear amplifying loop mirror. IEEE J. Selected Topics in Quant. Electron. 22: 1101208.

18. Wang Q, Teng H, Zou Y, Zhang Z, Li D, Wang R, Gao C, Lin J, Guo L and Wei Z, 2012. Graphene on $\mathrm{SiC}$ as a Q-switcher for a $2 \mu \mathrm{m}$ laser. Opt. Lett. 37: 395-397.

19. Lin X C, Zhang L, Tsang Y H, Wang Y G, Yu H J, Yan S L, Sun W, Yang Y Y, Han Z and Hou W, 2013. Multi-walled carbon nanotubes as a saturable absorber for a passively modelocked Nd: $\mathrm{YVO}_{4}$ laser. Laser Phys. Lett. 10: 055805.

20. Kukovecz Á., Kozma G and Kónya Z. Multi-walled carbon nanotubes, Ch. 5. In Springer handbook of nanomaterials. Ed. by R. Vajtai. Berlin-Heidelberg: Springer-Verlag (2013).

Babar I. M., Sabran M. B. S., Jusoh Z., Ahmad H., Harun S. W., Halder A., Paul M. C., Das S. and Bhadra S. K. 2014. Double-clad thulium/ytterbium co-doped octagonal-shaped fibre for fibre laser applications. Ukr.J.Phys.Opt. 15: 173 - 183.

Анотація. Ми дослідили характеристики лазерного випромінювання тулій/ітербієвого, спів-легованого волокна з восмикутним перетином та з подвійною оболонкою через яку здійснювалось нагнітання. Волокно виготовлялось методом модифікованого хімічно нанесення з парової фази, комбінованого з легуванням розчину. Воно характеризується поглинанням оболонки, спричиненим атомами $\mathrm{Tm}^{3+}$ i $\mathrm{Yb}^{3+}$, яке дорівнюе 0,325 ma 3,3 дБ/м, відповідно при 790 і 976 нм. Волоконний лазер, який функиіонував на трьох довжинах хвиль випромінювання 1914,5, 1934,7 і 1953,6 нм був сконструйований з використанням волокна довжиною 5 м в кільцевій конфігурації. При довжині волокна 15 м у кільцевому лазері досягалось найвище значення вихідної потужності 21.9 мВт при потужності нагнітання $3600 \mathrm{мBm}$ і найнижчий порогом нагнітання - $1000 \mathrm{мBm}$. При випромінювання на довжині хвилі 1961,4 нм досягалась максимальна ефективність генерації рівна 0,88\% для довжини підсилюючого середовища 10 м. Крім иього, було досліджено роботу тулій/ітербієвого волоконного лазера з модуляцією добротності та багато-стінковими вуглецевими нанотрубками, який випромінював на довжині хвилі 1977,5 нм. Встановлено, що зі зміною потужності випромінювання нагнітання з довжиною хвилі 905 нм з 1591,3 до 2261,5 мBm підвищується частота імпульсів з 18,8 до 50,6 кГи та зменшується тривалість імпульсів з 8,6 до 1,0 мкс. Максимальна енергія імпульсів, рівна 5,71 нДж, отримана при потужності нагнітання $2100 \mathrm{MBm}$.

Ukr. J. Phys. Opt. 2014, Volume 15, Issue 4 